\title{
Динаміка релігійної включеності населення свропейських країн
}

Світлана Сальнікова кандидат соиіологічних наук, дочент кафедри загальної і соиіальної психології та соичілогії, Східноєвропейський національний університет імені Лесі Українки, Луцьк, Україна

\section{Svitlana Salnikova -}

PhD in Sociology, Associate Professor, Department of General and Social Psychology, and Sociology Lesya Ukrainka Eastern European National University, Lutsk, Ukraine

E-mail: sv.salnikova@gmail.com Salnikova.Svitlana@eenu.edu.ua Researcher ID: S-5114-2017 ORCID: https://orcid.org/0000-00016368-9480

\section{Віталій Варійчук -}

магістр соиіології, кафедра загальної і соиіальної психологї та соиіології, Східноєвропейський національний університет імені Лесі Украӥнки, Луцькк, Україна

\section{Vitalii Variichuk -}

Master in Sociology, Department

of General and Social Psychology,

and Sociology

Lesya Ukrainka Eastern European

National University, Lutsk, Ukraine

E-mail: varich96@gmail.com

ORCID: https://orcid.org/0000-0001-

8299-3357

DOI: https://doi.org/10.29038/2306-

3971-2019-01-69-77

Reseived: February, 2019

$1^{\text {st }}$ Revision: March, 2019

Accepted: April, 2019
Попри загальну тенденцію до секуляризації в сучасному світі, інститут релігії відіграє важливу роль у соціальному та державницькому розвитку суспільства.

Послуговуючись даними європейського соціального дослідження (2008-2016) і методикою вимірювання релігійної включеності (С. Сальнікова), яка грунтується на релевантних показниках релігійності (Дж. Біллет), автори здійснили аналіз рівня та характеру релігійності низки європейських країн. Рівень релігійності є показником суб'єктивної інституційної належності; під характером релігійності розуміємо розподіл змінної «релігійна включеність», яка поділяється на когорти тих, хто належить до основного, модального й маргінального типів релігійної включеності (це тип воцерковленої релігійності), культурного типу (це релігійно-культурна ідентифікація) та неоцерковлених у 1- й 2-му поколіннях.

Виявлено, що динаміка інституційної релігійності характерна більшості країн, а у випадку іï відсутності динамічними є процеси, пов'язані з характером релігійності. Виняток становить Польща.

Незалежно від загального рівня релігійності, аналіз даних щодо 15 країн Європи виявляє такі тенденції релігійних змін, як стабільність (Польща, Франція, Бельгія, Естонія, Чехія), посилення інституційної релігійності (Німеччина, Словенія, Швеція) або іiі маргіналізація чи посилення секулярних впливів (Португалія, Іспанія, Швейцарія, Нiдерланди, Угорщина, Фінляндія, Норвегія). Зниження рівня релігійності в багатьох країнах відбувається за рахунок збільшення когорти неоцерковлених в 1-му та/або 2-му поколіннях.

Salnikova Svitlana, Variichuk Vitalii. Dynamics of Religious Involvement of the Population of European Countries. Despite the general tendency towards secularization in the modern world, the institute of religion still has an important role in the social and state development of society. 
Using the data of the European Social Survey (2008-2016) and the methodic for measuring religious involvement (S. Salnikova), which is based on relevant indicators of religiosity (J. Billiet), the authors analyzed the level and character of religiosity in a number of European countries. The level of religiosity is an indicator of subjective institutional belonging to particular religion or denomination; under the character of religiosity, we mean the division of the variable religious involvement, which is divided into the cohort of those belonging to the main, modal and marginal types of religious involvement (these are types of in-church religious belonging), cultural type (this is a religious and cultural identification), and non-church types (in the 1st and 2nd generation).

It is revealed that the dynamics of institutional religiosity is characteristic of most countries, and in case of its absence, processes related to the character of religiosity are dynamic. Exception is Poland. Regardless of the general level of religiosity, the analysis of data in 15 European countries reveals such tendencies in religious changes as stability (Poland, France, Belgium, Estonia, Czech Republic), strengthening of institutional religiosity (Germany, Slovenia, Sweden) or its marginalization or strengthening of secular influences (Portugal, Spain, Switzerland, the Netherlands, Hungary, Finland, Norway). Reducing the level of religiosity in many countries is due to an increase in the non-church cohorts in the 1st and / or 2nd generations.

Key words: religiosity, religious attendance, religious participation, types of religiosity, European Social Survey.

Сальникова Светлана, Варийчук Виталий. Динамика религиозной вовлеченности населения европейских стран. Исследование базируется на данных Европейского социального исследования (2008-2016) с использованием методики измерения религиозной включенности (С. Сальникова). Под религиозной включенностью автор методики понимает религиозную принадлежность и религиозные практики. Комбинация разных возможных вариантов позволяет построить переменную, чувствительную к таким типам религиозности, как основной, модальный, маргинальный (это воцерковленные типы религиозности), культурный (религиозно-культурная идентификация) и неоцерковленные в 1- и 2-м поколениях. Выявлено, что динамика институциональной религиозности характерна большинству стран, в случае ее отсутствия динамичными будут процессы, связанные с характером религиозности. Исключением является Польша.

Ключевые слова: религиозность, религиозная принадлежность, религиозное участие, типы религиозности, Европейское социальное исследование.

Постановка наукової проблеми та їі значення. Попри загальну тенденцію до секуляризації в сучасному модерному світі, інституційно релігія все ще відіграє важливу роль у соціальному та державницькому розвитку суспільства. Релігія проникає в різні сфери життя й закріплюється там як невід'ємний елемент. Не слід ігнорувати роль релігії не лише у формуванні зв'язків між індивідами, морально-етичних комплексів та ціннісних орієнтацій людини, у процесі соціалізації й інкультурації, а й у соціально-політичній, соціально-економічній сферах окремого суспільства та/чи певних держав. Інтегральний фактор релігії потребує постійного вивчення й аналізу, і спостережувана динаміка релігійності описує не лише зміни в самому інституті релігії, секуляризованість суспільства, а й прогнозну здатність впливати на різні сфери життєдіяльності спільнот.

Аналіз досліджень цієї проблеми має доволі розмаїтий характер. Дослідники висловлюють свої думки стосовно того, у які сфери проникає релігія і як вона пов'язана зі змінами в суспільстві (Роllack, 2008), сприяє накопиченню соціального капіталу (Coleman, 1988; Musick, 2004), як вона впливає на політичне життя суспільства (Norris, Inglehart, 2004) та відчуття власного благополуччя (Тsaousis, Karademas, Kalatzi, 2012), про іï зв’язок з епохою модерну (Тейлор, 2014; Riesebrodt, 2014), про зв'язок теорії секуляризації та теорії раціонального вибору (Stol, 2008) й ін. Чи не основну ідею про характер секуляризації висловив X. Казанова, зауваживши про те, що «теоріям секуляризації важче відповісти іншим критикам, які зазначають, що модерні бар'єри між церквою та державою дедалі більше руйнуються з обох боків, тож обидві сторони можуть проникати одна в одну; що релігійні інституції часто відмовляються визнати призначене їм маргінальне місце в приватній сфері, натомість їм удається відігравати провідні публічні ролі; що релігія й політика далі створюють різноманітні симбіотичні стосунки...» (Казанова, 2017, с. 17).

Емпіричну базу дослідження становлять масиви даних Європейського соціального дослідження (ESS) за 2008-2016 pр. Методологія вимірювання релігійності в цьому порівняльному проекті заснована на низці релевантних показників (Billiet, 2004). Дж. Біллет довів порівнюваність таких показників, як теперішня та минула релігійні належності, частота здійснення молитов і відвідування церкви. Спираючись на напрацювання Дж. Біллета, український соціолог С. Сальнікова запропонувала методику вимірювання релігійності, яка має темпоральну властивість; опис методики представлено в статті 
«Религиозный капитал и религиозное участие в странах новой восточной Европы» (Миронович, Решетняк, Сальникова, 2013).

Для аналізу відібрано ті європейські країни, які брали участь у всіх аналізованих хвилях дослідження. Це - Польща, Португалія, Іспанія, Швейцарія, Угорщина, Німеччина, Фінляндія, Норвегія, Словенія, Франція, Бельгія, Нідерланди, Швеція, Естонія та Чехія. Україна, на жаль, представлена лише в декількох хвилях.

Мета роботи - представлення динаміки релігійності окремих європейських країн згідно 3 методикою С. Сальнікової. Отже, завдання дослідження зосереджено на (1) створенні змінної за запропонованою методикою, (2) отриманні даних на їі основі та (3) інтерпретації результатів.

Виклад основного матеріалу та обгрунтування отриманих результатів дослідження. Теорія соціального капіталу є рамковою для вивчення релігійної включеності, адже активна належність до певної групи сприяє формуванню соціального капіталу. Дж. Колеман визначає останній як певний аспект співпраці індивідів у соціальних структурах, де певний актор або колектив акторів працює як цілісний механізм, у якому кожен елемент має можливість отримати користь від перебування в цій структурі (Coleman, 1988). Якщо додати до такого визначення релігійний аспект, а саме відчуття індивіда, який належить до певної релігійної групи, то можна сказати, що релігійний капітал - це мережа соціальних зв'язків окремих індивідів, що відчувають себе включеними в певну структуру, тобто релігійний інститут, від чого вони можуть мати реальну користь для себе, а також можливість допомагати й іншим, тобто обмінюватись особистим капіталом. Відчуття належності індивіда до інших індивідів, у яких $\epsilon$ спільний зв'язний фактор у вигляді релігії, називають інституційною релігійністю. Люди, котрі належать до певних релігійних інституцій, схильні до допомоги один одному та побудови щільних і стійких соціальних зв'язків, у результаті чого з'являються різні волонтерські організації та співробітництво в середині сформованої структури (Musick, 2004, p. 210). На такому рівні вона зберігає цілісність суспільства, а на індивідуальному рівні вона доволі динамічна й мінлива (Федоренко, 2013, с. 240). Релігія може впливати на формування певних моральних якостей людини (Good, 2013, p. 4), а нормування/ регулювання iii поведінки залежить від того, наскільки активною є релігійна діяльність індивіда (Schieman, 2008, p. 288; Кормина, 2017, с. 136). Тут вимірювання релігійних практик є мірою релігійної поведінки індивіда (Giorgi, 1992, p. 641).

Отож, показник відвідування церкви має велике значення під час визначення рівня релігійності населення в цілому. Він не просто доповнює релігійну належність індивіда чи його суб'єктивну оцінку власної релігійності, адже людина може віднести себе до будь-якої відомої релігії, маркуючи таким чином релігійну культуру, у якій соціалізувалася; проте якщо вона ще й активно діє в середині вибраної релігійної групи, то це можна розцінювати як вияв справжньої усвідомленої релігійності.

Звідси ми стверджуємо те, що релігійна належність у поєднанні з релігійною участю демонструє релігійну включеність. При цьому використання минулої й теперішньої релігійної належності уможливлює вивчення релігійної включеності в темпоральному вимірі. Правило побудови нової змінної «релігійна включеність» подано нижче.

Побудова змінної релігійної включеності

Табличя 1

\begin{tabular}{|l|c|c|c|}
\hline \multicolumn{1}{|c|}{ Тип уключеності } & $\begin{array}{c}\text { Теперішня } \\
\text { приналежність }\end{array}$ & $\begin{array}{c}\text { Колишня } \\
\text { приналежність }\end{array}$ & Частота відвідування \\
\hline Основний & Так & - & Більш ніж щомісячно \\
\hline Модальний & Так & - & Тільки на свята \\
\hline Маргінальний & Так & - & Нерегулярно \\
\hline Культурний & $\begin{array}{l}\text { Так } \\
\text { Нi / Не знаю }\end{array}$ & - & $\begin{array}{c}\text { Ніколи } \\
\text { Заперечна відповідь }\end{array}$ \\
\hline $\begin{array}{l}\text { Неоцерковлені в } \\
\text { 1-му поколінні }\end{array}$ & $\mathrm{Hi} /$ Не знаю & Так & Ніколи \\
\hline $\begin{array}{l}\text { Неоцерковлені в } \\
\text { 2-му поколінні }\end{array}$ & Ні / Не знаю & Ні & Ніколи \\
\hline Нерелевантні & Ні / Не знаю & $\begin{array}{c}\text { Так / Ні } \\
\text { Не знаю }\end{array}$ & $\begin{array}{c}\text { Ніколи } \\
\text { Не знаю }\end{array}$ \\
\hline
\end{tabular}

Джерело: (Миронович, Решетняк, Сальникова, 2013, с. 22). 
Послуговуючись правилом, поданим у табл. 1, створили програму в SPSS Syntax, яка автоматично побудувала змінну релігійної включеності, перші три категорії котрої - основний, модальний i маргінальний типи - можна інтерпретувати як міру інституційної релігійної включеності, наступну, культурний тип, - як релігійно-культурну належність, категорії неоцерковленості означають відсутність інституційної релігійної належності, причому в часовому вимірі. Перетікання долей між зазначеними типами релігійної включеності в динаміці демонструє напрям релігійних змін, які потребують додаткового грунтовного вивчення.

Показово, що країни 3 домінуванням католицизму демонструють вищий рівень інституційної релігійності. Такими є Польща (від 92,1 \% у 2008 р. до 90 \% у 2016 р.), Португалія (від 87,5 \% у 2008 р. до 75,7 \% у 2016 р.), Іспанія (від 72 \% у 2008 р. до 67 \% у 2016 р.).

\section{Релігійна включеність, ЄСД, Полыща, Португалія, Іспанія}

Таблиия 2

\begin{tabular}{|c|c|c|c|c|c|c|c|c|c|c|}
\hline \multirow[b]{3}{*}{ Країна } & \multirow[b]{3}{*}{ Рік } & \multicolumn{8}{|c|}{ Тип релігійної включеності } & \multirow{3}{*}{ 告 } \\
\hline & & \multirow[b]{2}{*}{ 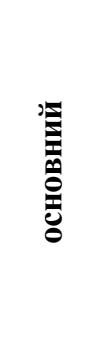 } & \multirow[b]{2}{*}{ 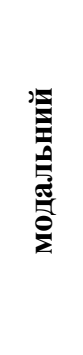 } & \multirow[b]{2}{*}{ 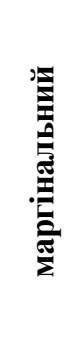 } & \multirow[b]{2}{*}{ 产 } & \multicolumn{2}{|c|}{ неоцерковлені } & \multirow[b]{2}{*}{ 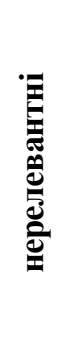 } & \multirow[b]{2}{*}{ 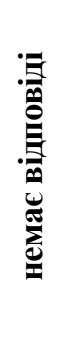 } & \\
\hline & & & & & & 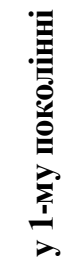 & 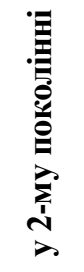 & & & \\
\hline 1 & 2 & 3 & 4 & 5 & 6 & 7 & 8 & 9 & 10 & 11 \\
\hline \multirow{5}{*}{ Польща } & 2008 & 69,9 & 17,0 & 2,9 & 3,9 & 1,6 & 2,2 & 2,5 & 0,1 & 92,1 \\
\hline & 2010 & 69,4 & 16,6 & 2,5 & 3,8 & 2,4 & 2,2 & 2,9 & 0,2 & 90,7 \\
\hline & 2012 & 67,2 & 15,5 & 3,6 & 5,0 & 2,4 & 2,7 & 3,3 & 0,2 & 89,3 \\
\hline & 2014 & 69,5 & 15,3 & 3,3 & 4,9 & 2,5 & 2,0 & 2,4 & 0,0 & 90,5 \\
\hline & 2016 & 66,0 & 17,1 & 3,5 & 5,2 & 2,5 & 1,9 & 3,5 & 0,1 & 90,0 \\
\hline \multirow{5}{*}{ Португалія } & 2008 & 46,3 & 10,7 & 13,3 & 18,7 & 3,4 & 5,8 & 1,7 & 0,0 & 87,5 \\
\hline & 2010 & 43,7 & 13,9 & 15,0 & 16,5 & 2,5 & 6,8 & 1,6 & 0,0 & 86,9 \\
\hline & 2012 & 38,4 & 12,1 & 18,4 & 17,1 & 4,7 & 8,1 & 1,1 & 0,0 & 83,5 \\
\hline & 2014 & 42,6 & 11,8 & 13,6 & 13,7 & 4,6 & 10,1 & 3,6 & 0,0 & 76,0 \\
\hline & 2016 & 41,6 & 7,7 & 16,9 & 14,3 & 6,9 & 10,3 & 2,4 & 0,0 & 75,7 \\
\hline \multirow{5}{*}{ Іспанія } & 2008 & 25,1 & 13,1 & 13,1 & 23,3 & 10,8 & 12,1 & 2,6 & 0,0 & 72,0 \\
\hline & 2010 & 23,6 & 18,9 & 11,3 & 18,8 & 9,8 & 11,5 & 6,2 & 0,0 & 68,5 \\
\hline & 2012 & 24,1 & 15,3 & 10,0 & 18,4 & 13,8 & 13,2 & 5,2 & 0,0 & 65,4 \\
\hline & 2014 & 22,8 & 11,4 & 13,3 & 22,7 & 13,9 & 12,9 & 2,8 & 0,3 & 66,1 \\
\hline & 2016 & 23,8 & 12,3 & 14,6 & 19,8 & 14,7 & 12,4 & 2,5 & 0,0 & 67,0 \\
\hline
\end{tabular}

Із-поміж трьох країн лише Польща має стабільно високий рівень інституційної релігійності, і відмінності в когорті основного типу релігійно включених та неоцерковлених у 1-му поколінні, які простежуються за період 2008-2016 рр., не є статистично значущими. У двох інших державах тенденцію до спаду інституційної релігійності простежено достатньо чітко. Проте в Іспанії цей процес відбувається за рахунок збільшення когорти неоцерковлених у 1-му поколінні - іспанське суспільство поволі секуляризується, а в Португалії інституційна релігійність маргіналізується, збільшуючи одночасно когорти неоцерковлених і в 1-му, і в 2-му поколіннях, тут інститут релігії втрачає свою впливовість.

У Португалії чітко виражено тенденцію до секуляризації. Рівень інституційної релігійності в цій країні знижується зі зростанням частки неоцерковлених у другому поколінні.

В Іспанії тенденція до секуляризації має ситуаційний характер. Проте, порівнявши рівень інституційної релігійності та основного типу релігійної включеності за 2008 та 2016 рр., можемо побачити, що роль релігії в цій країні дещо здає свої позиції. 
Картина в державах із наявністю одразу двох важливих релігійних традицій - протестантської та католицької - не зовсім однозначна (див. табл. 3). Ці країни представлені Швейцарією, Німеччиною та Нідерландами.

У Швейцарії виражена тенденція до секуляризації, адже зниження рівня релігійності в країні в цілому (із 68,9 \% у 2008 р. до 61,2 \% у 2016 р.) першочергово пов'язане зі зростанням когорти неоцерковлених у 1- та 2-му поколіннях.

У Німеччині ситуація щодо інституційної релігійності відносно стабільна, проте відбулися великі зміни в характері релігійності німців. Починаючи від 2010 р., у німецькому суспільстві, з одного боку, збільшилася вдвічі когорта неоцерковлених у 1-му поколінні (із 5 до $10 \%$ у 2008 р. й 2010-2016 pp. відповідно) та найбільш оцерковлених громадян (основний тип релігійної включеності), друга когорта наповнилася переважно за рахунок тих, хто ідентифікував себе з певною релігією як культурою або ж був на маргінесі оцерковлених.

У Нідерландах рівень інституційної релігійності спадає; вплив секуляризації проявляється в збільшенні когорт неоцерковлених громадян.

Отож, ситуація в країна 3 домінуванням двох релігійних традицій (протестантської й католицької) неоднорідна, тенденція до секуляризації виражена у Швейцарії та Нідерландах, тоді як у Німеччині - до посилення оцерковлення.

Релігійна включеність, ЄСД, Швейцарія, Німеччина, Нідерланди

\begin{tabular}{|c|c|c|c|c|c|c|c|c|c|c|}
\hline \multirow[b]{3}{*}{ Країна } & \multirow[b]{3}{*}{ Рік } & \multicolumn{8}{|c|}{ Тип релігійної включеності } & \multirow{3}{*}{ 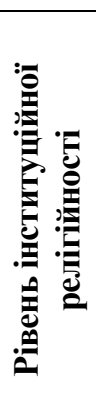 } \\
\hline & & \multirow[b]{2}{*}{ 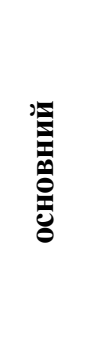 } & \multirow[b]{2}{*}{ 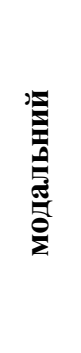 } & \multirow[b]{2}{*}{ 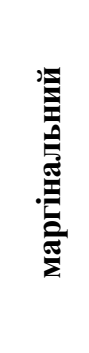 } & \multirow[b]{2}{*}{ 资 } & \multicolumn{2}{|c|}{ неоцерковлені } & \multirow[b]{2}{*}{ 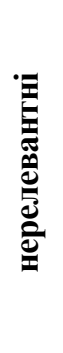 } & \multirow[b]{2}{*}{ 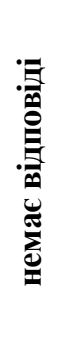 } & \\
\hline & & & & & & 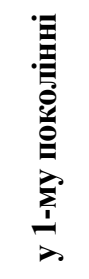 & 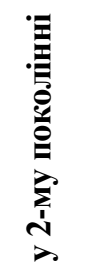 & & & \\
\hline 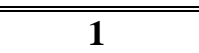 & 2 & 3 & 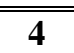 & 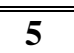 & $\overline{6}$ & 7 & 8 & 9 & $\overline{10}$ & 11 \\
\hline \multirow{5}{*}{ Швейцарія } & 2008 & 20,2 & 21,1 & 15,0 & 19,4 & 7,9 & 11,9 & 4,5 & 0,0 & 68,9 \\
\hline & 2010 & 21,9 & 16,7 & 15,8 & 20,3 & $\begin{array}{l}9,8 \\
\end{array}$ & 10,5 & 5,0 & 0,0 & 67,9 \\
\hline & 2012 & 20,3 & 18,7 & 13,6 & 19,4 & 9,7 & 12,8 & 5,5 & 0,0 & 63,9 \\
\hline & 2014 & 19,6 & 20,4 & 13,6 & 17,5 & 9,1 & 14,4 & 5,5 & 0,0 & 63,3 \\
\hline & 2016 & 17,7 & 18,6 & 14,8 & 18,8 & 9,8 & 14,2 & 6,0 & 0,0 & 61,2 \\
\hline \multirow{5}{*}{ Німеччина } & 2008 & 9,4 & 18,0 & \begin{tabular}{ll|}
17,9 \\
\end{tabular} & 24,0 & 4,7 & 19,5 & 6,5 & 0,0 & 60,2 \\
\hline & 2010 & 19,0 & 18,5 & 14,7 & 16,4 & 10,5 & 17,0 & 3,9 & 0,0 & 62,2 \\
\hline & 2012 & 19,3 & 18,6 & 14,5 & 15,5 & 9,1 & 18,8 & 4,1 & 0,0 & 62,6 \\
\hline & 2014 & 18,5 & 18,4 & 13,4 & 17,5 & 9,2 & 19,2 & 3,9 & 0,0 & 60,8 \\
\hline & 2016 & 18,7 & 17,8 & 14,4 & 15,6 & 10,1 & 19,1 & 4,2 & 0,0 & 60,6 \\
\hline \multirow{5}{*}{ Нідерланди } & 2008 & 21,3 & 6,6 & 7,6 & 14,4 & 12,7 & 30,8 & 6,6 & 0,0 & 41,8 \\
\hline & 2010 & 18,4 & 8,2 & 6,2 & 14,8 & 14,2 & 32,3 & 6,0 & 0,0 & 41,0 \\
\hline & 2012 & 17,2 & 6,2 & 6,0 & 13,5 & 18,1 & 33,3 & 5,7 & 0,0 & 36,8 \\
\hline & 2014 & 16,2 & 7,5 & 6,5 & 14,7 & 16,4 & 33,5 & 5,3 & 0,0 & 37,6 \\
\hline & 2016 & 14,1 & 6,5 & 5,4 & 13,6 & 19,6 & 35,5 & 5,4 & 0,0 & 32,0 \\
\hline
\end{tabular}

У країнах із рівнем інституційної релігійності 50-60\% ситуація різна. Наприклад, рівень релігійності населення в Угорщині та Фінляндії знижується переважно за рахунок збільшення когорти неоцерковлених у 2-му поколінні і зменшення релігійних маргіналів (див. табл. 4), у Норвегії - через переструктурування когорт модального й культурного типів релігійної включеності, зростання неоцерковленості (див. табл. 4). 


\section{Релігійна включеність, ЄСД, Угорщина, Фінляндія, Норвегія}

\begin{tabular}{|c|c|c|c|c|c|c|c|c|c|c|}
\hline \multirow[b]{3}{*}{ Країна } & \multirow[b]{3}{*}{ Рік } & \multicolumn{8}{|c|}{ Тип релігійної включеності } & \multirow{3}{*}{ 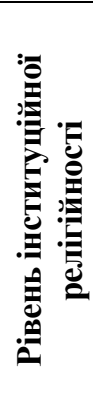 } \\
\hline & & \multirow[b]{2}{*}{ 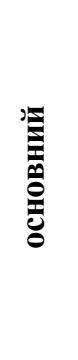 } & \multirow[b]{2}{*}{ 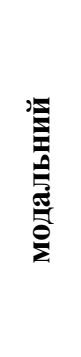 } & \multirow[b]{2}{*}{ 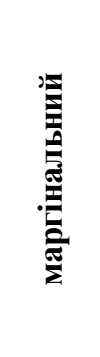 } & \multirow[b]{2}{*}{ 瓷 } & \multicolumn{2}{|c|}{ неоцерковлені } & \multirow[b]{2}{*}{ 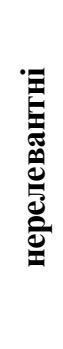 } & \multirow[b]{2}{*}{ 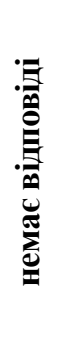 } & \\
\hline & & & & & & 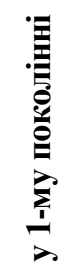 & 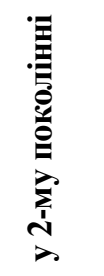 & & & \\
\hline 1 & 2 & 3 & 4 & 5 & 6 & 7 & 8 & 9 & 10 & 11 \\
\hline \multirow{5}{*}{ Угорщина } & 2008 & 16,1 & 16,6 & 18,6 & 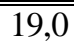 & 3,2 & 21,4 & 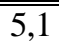 & 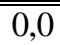 & 60,9 \\
\hline & 2010 & 16,4 & 15,5 & 15,9 & 20,9 & 2,7 & 22,9 & 5,7 & 0,0 & 58,9 \\
\hline & 2012 & 12,7 & 11,5 & 13,5 & 22,2 & 2,1 & 30,0 & 8,0 & 0,0 & 47,4 \\
\hline & 2014 & 13,3 & 16,4 & 12,4 & 19,6 & 2,1 & 27,7 & 8,5 & 0,0 & 49,7 \\
\hline & 2016 & 14,8 & 16,9 & 11,5 & 18,4 & 1,5 & 29,6 & 7,2 & 0,0 & 51,5 \\
\hline \multirow{5}{*}{ Фінляндія } & 2008 & 111,8 & 16,0 & 23,0 & 23,5 & 4,9 & 12,7 & 8,2 & 0,0 & 599,0 \\
\hline & 2010 & 12,9 & 17,5 & 23,0 & 21,6 & 5,8 & 13,4 & 5,7 & 0,0 & 60,9 \\
\hline & 2012 & 10,2 & 13,9 & 19,5 & 27,1 & 5,6 & 16,7 & 7,1 & 0,0 & 50,2 \\
\hline & 2014 & 11,8 & 14,4 & 18,3 & 26,0 & 5,5 & 15,9 & 8,2 & 0,0 & 50,4 \\
\hline & 2016 & 11,0 & 15,3 & 21,9 & 23,3 & 5,8 & 16,5 & 6,2 & 0,0 & 55,3 \\
\hline \multirow{5}{*}{ Норвегія } & 2008 & 9,2 & 16,6 & 15,9 & 25,0 & 7,7 & 18,9 & $\overline{6,6,6}$ & $\overline{0.0,0}$ & 56,1 \\
\hline & 2010 & 10,4 & 18,3 & 15,5 & 24,4 & 5,9 & 19,1 & 6,5 & 0,0 & 58,7 \\
\hline & 2012 & 10,4 & 15,4 & 13,9 & 23,3 & 6,5 & 21,3 & 9,2 & 0,0 & 51,0 \\
\hline & 2014 & 9,7 & 14,9 & 14,1 & 21,4 & 8,1 & 22,0 & 9,7 & 0,0 & 48,7 \\
\hline & 2016 & 10,9 & 17,7 & 14,1 & 20,8 & 10,4 & 19,4 & 6,6 & 0,1 & 53,3 \\
\hline
\end{tabular}

У Словенії інститут релігії дещо посилив свої позиції (із 55,1 до 52,6 \% у 2008 р. та 2016 р. відповідно), збільшивши когорту модально релігійних (табл. 5). А от у Франції підвищення рівня інституційної релігійності (із 47,1 до 61,5 \% у 2008 р. і 2016 р. відповідно) відбулося за рахунок тих, хто себе лише маркує релігійними (табл. 5).

Таблиия 5

Релігійна включеність, ЄСД, Словенія, Франція

\begin{tabular}{|c|c|c|c|c|c|c|c|c|c|c|}
\hline \multirow[b]{3}{*}{ Країна } & \multirow[b]{3}{*}{ Рік } & \multicolumn{8}{|c|}{ Тип релігійної включеності } & \multirow{3}{*}{ 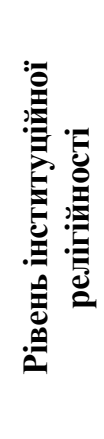 } \\
\hline & & \multirow[b]{2}{*}{ 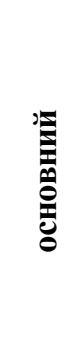 } & \multirow[b]{2}{*}{ 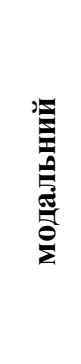 } & \multirow[b]{2}{*}{ 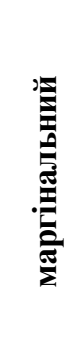 } & \multirow[b]{2}{*}{ 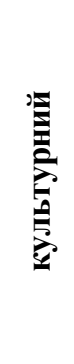 } & \multicolumn{2}{|c|}{ неоцерковлені } & \multirow[b]{2}{*}{ 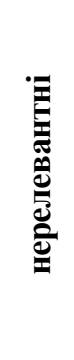 } & \multirow[b]{2}{*}{ 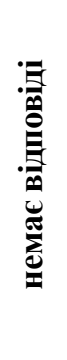 } & \\
\hline & & & & & & 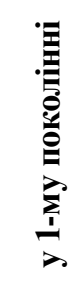 & 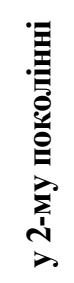 & & & \\
\hline$\overline{1.1}$ & 2 & 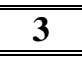 & 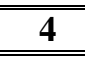 & $\overline{5}$ & 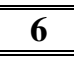 & 7 & $\overline{88}$ & 9 & $\overline{10}$ & 11 \\
\hline \multirow{5}{*}{ Словенія } & 2008 & 23,6 & 21,2 & $\frac{\bar{c} 6,4}{6,4}$ & 14,5 & 2,4 & $\begin{array}{lll}18,7 \\
\end{array}$ & 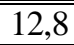 & $\overline{c 0,5}$ & $\begin{array}{l}55,1 \\
\end{array}$ \\
\hline & 2010 & 21,4 & 24,9 & 4,3 & 11,2 & 2,3 & 22,0 & 13,8 & 0,0 & 54,2 \\
\hline & 2012 & 21,0 & 21,6 & 7,2 & 10,7 & 3,7 & 23,6 & 12,3 & 0,0 & 55,2 \\
\hline & 2014 & 20,5 & 23,8 & 5,8 & 13,6 & 3,7 & 20,0 & 12,4 & 0,2 & 57,1 \\
\hline & 2016 & 22,6 & 27,0 & 6,0 & 11,9 & 2,8 & 19,2 & 10,4 & 0,1 & 61,5 \\
\hline
\end{tabular}


Закінчення таблиці 5

\begin{tabular}{|c|c|c|c|c|c|c|c|c|c|c|}
\hline \hline $\mathbf{1}$ & $\mathbf{2}$ & $\mathbf{3}$ & $\mathbf{4}$ & $\mathbf{5}$ & $\mathbf{6}$ & $\mathbf{7}$ & $\mathbf{8}$ & $\mathbf{9}$ & $\mathbf{1 0}$ & $\mathbf{1 1}$ \\
\hline \hline \multirow{5}{*}{ Франція } & 2008 & 11,0 & 14,5 & 9,0 & 19,6 & 10,7 & 29,7 & 5,6 & 0,0 & 47,1 \\
\cline { 2 - 10 } & 2010 & 12,6 & 13,2 & 10,2 & 20,9 & 7,6 & 30,3 & 5,0 & 0,0 & 49,1 \\
\cline { 2 - 10 } & 2012 & 9,9 & 12,4 & 10,4 & 22,6 & 9,1 & 29,9 & 5,7 & 0,0 & 47,7 \\
\cline { 2 - 10 } & 2014 & 11,8 & 12,6 & 8,7 & 20,9 & 9,5 & 31,1 & 5,5 & 0,0 & 46,3 \\
\cline { 2 - 9 } & 2016 & 10,9 & 14,1 & 10,8 & 23,3 & 9,0 & 27,5 & 4,5 & 0,0 & 52,6 \\
\hline
\end{tabular}

У країнах із низьким рівнем інституційної релігійності - Бельгія, Швеція, Чехія, Естонія - говорити про значимі зміни стосовно характеру релігійності населення не можна. Відмінності тут проглядаються в тому, що лише Бельгія має значимий відсоток неоцерковлених у 1-му поколінні громадян, тоді як Швеція, Чехія, Естонія - ні.

Релігійна включеність, ССД, Бельгія, Швеція, Естонія, Чехія

\begin{tabular}{|c|c|c|c|c|c|c|c|c|c|c|}
\hline \multirow[b]{3}{*}{ Країна } & \multirow[b]{3}{*}{ Рік } & \multicolumn{8}{|c|}{ Тип релігійної включеності } & \multirow{3}{*}{ 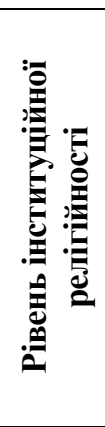 } \\
\hline & & \multirow[b]{2}{*}{ 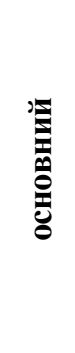 } & \multirow[b]{2}{*}{ 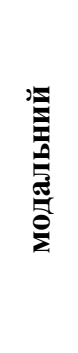 } & \multirow[b]{2}{*}{ 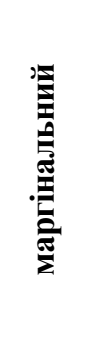 } & \multirow[b]{2}{*}{ 瓷 } & \multicolumn{2}{|c|}{ неоцерковлені } & \multirow[b]{2}{*}{ 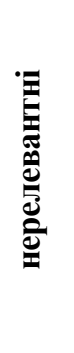 } & \multirow[b]{2}{*}{ 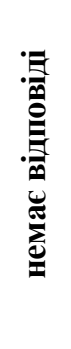 } & \\
\hline & & & & & & 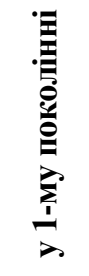 & 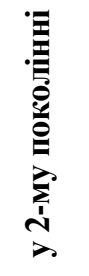 & & & \\
\hline 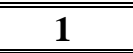 & 2 & 3 & 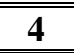 & 5 & 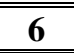 & 7 & 8 & 9 & 10 & 11 \\
\hline \multirow{5}{*}{ Бельгія } & 2008 & 13,8 & 9,9 & 9,9 & 18,8 & 11,1 & 29,4 & 7,3 & 0,0 & 43,5 \\
\hline & 2010 & 13,0 & 8,0 & 7,3 & 20,8 & 13,6 & 31,3 & 5,9 & 0,0 & 41,8 \\
\hline & 2012 & 11,8 & 7,4 & 8,6 & 19,8 & 14,1 & 32,0 & 6,3 & 0,0 & 40,3 \\
\hline & 2014 & 13,5 & 8,2 & 6,8 & 19,7 & 12,6 & 32,3 & 6,8 & 0,0 & 40,0 \\
\hline & 2016 & 13,0 & 9,1 & 11,4 & 20,1 & 14,7 & 27,2 & 4,6 & 0,0 & 45,4 \\
\hline \multirow{5}{*}{ Швеція } & 2008 & 8,3 & 7,2 & 11,0 & 26,8 & 3,5 & 31,5 & 11,8 & 0,0 & 31,1 \\
\hline & 2010 & 7,9 & 6,3 & 10,5 & 29,7 & 3,7 & 31,5 & 10,4 & 0,0 & 30,1 \\
\hline & 2012 & 9,2 & 7,9 & 10,9 & 25,4 & 4,7 & 27,7 & 14,2 & 0,0 & 32,4 \\
\hline & 2014 & 7,7 & 7,8 & 10,1 & 28,2 & 5,5 & 27,9 & 12,8 & 0,0 & 30,1 \\
\hline & 2016 & 10,1 & 9,1 & 11,9 & 28,2 & 4,3 & 27,4 & 9,1 & 0,0 & 36,2 \\
\hline \multirow{5}{*}{ Естонія } & 2008 & $7,7,5$ & 8,4 & 8,1 & 22,8 & 1,3 & 29,5 & 22,3 & \begin{tabular}{ll|l}
0,0 \\
\end{tabular} & 26,4 \\
\hline & 2010 & 6,4 & 7,6 & 4,2 & 23,8 & 0,6 & 32,3 & 25,2 & 0,0 & 20,3 \\
\hline & 2012 & 6,7 & 10,1 & 9,8 & 20,4 & 0,6 & 31,9 & 20,5 & 0,0 & 29,7 \\
\hline & 2014 & 9,0 & 11,0 & 11,0 & 22,2 & 1,0 & 26,3 & 19,4 & 0,0 & 35,2 \\
\hline & 2016 & 6,7 & 11,1 & 8,1 & 20,7 & 1,0 & 33,0 & 19,5 & 0,0 & 28,4 \\
\hline \multirow{5}{*}{ Чехія } & 2008 & 8,6 & 7,0 & $\begin{array}{l}4,3 \\
\end{array}$ & 111,6 & 3,5 & $\begin{array}{l}57,3 \\
\end{array}$ & 7,4 & 0,2 & 22,3 \\
\hline & 2010 & 8,1 & 6,0 & 4,1 & 12,4 & 1,5 & 61,1 & 6,7 & 0,1 & 21,2 \\
\hline & 2012 & 8,0 & 5,1 & 2,9 & 18,6 & 1,0 & 54,2 & 8,9 & 1,4 & 18,2 \\
\hline & 2014 & 8,5 & 3,9 & 1,8 & 13,5 & 0,7 & 60,0 & 11,6 & 0,0 & 15,5 \\
\hline & 2016 & 6,4 & 6,3 & 3,7 & 12,1 & 1,1 & 58,3 & 12,0 & 0,0 & 18,4 \\
\hline
\end{tabular}

Висновки та перспективи подальших досліджень. Динаміка релігійної включеності європейських країн, які брали участь у ЄСД 2008-2016 рр., демонструє не лише різний рівень інституційної релігійності населення, а й відмінності в характері релігійності. Серед країн із високим рівнем релігійності можна виокремити Польщу, Португалію, Іспанію, Швейцарію та Німеччину. Усі показники Польщі є фактично незмінними, тоді як зовні незмінна 60-відсоткова релігійність німців змістилася в бік 
посилення оцерковленості. Зниження рівня релігійності в решти країнах відбувається за рахунок збільшення когорти неоцерковлених у 1- та/або 2-му поколіннях.

Незалежно від загального рівня релігійності, аналіз даних по 15 країнах Європи виявляє такі тенденції релігійних змін, як стабільність (Польща, Франція, Бельгія, Естонія, Чехія), посилення інституційної релігійності (Німеччина, Словенія, Швеція) або іiі маргіналізація чи посилення секулярних впливів (Португалія, Іспанія, Швейцарія, Нідерланди, Угорщина, Фінляндія, Норвегія).

Перспективними були б порівняльні дані в розрізі віку, статі, освіти, статусу, рівня доходів тощо.

\section{Джерела та література}

1. Казанова, Х. (2017). По той бік секуляризаиії: Релігійна та секулярна динаміка нашої глобальної доби. Київ: Дух і літера.

2. Кормина, Ж., Панченко, А., Штырков, С. (2017). Социальное исследование религии: Теория, методы и опыт. Антропологический форум, № 35, 129-166.

3. Сальникова, С., Миронович, Д., Решетняк, Е. (2013). Религиозный капитал и религиозное участие в странах новой восточной. Вісник Київського національного університету імені Тараса Шевченка: Соціологія, Вип. 1, 16-27.

4. Тейлор, Ч. (2014). Секулярность и религия. Богословие. Культура Образование. 18:3, 395-410.

5. Федоренко, М. И. (2013). Религиозность, идентификация и религиозная идентичность. Ученые записки ОГУ. Серия: Гуманитарные и социальные науки, № 4, 239-241.

6. Billiet, J., Welkenhuysen-Gybels, J. (2004). Assessing Cross-National Construct Equivalence in the ESS: The Case of Religious Involvement. Paper presented at the European Conference on Quality and Methodology in Official Statistics, Mainz (Germany), 24-26 May.

7. Coleman, J. S. (1988). Social Capital in the Creation of Human Capital. American Journal of Sociology, Vol. 94, 95-120.

8. Giorgi, L. (1992). Religious Involvement in a Secularized Society. The British Journal of Sociology, Vol. 43, No. 4, 639-656.

9. Good, M., Willoughby, T. (2013). Institutional and Personal/Spirituality Religiosity and Psychosocial Adjustment in Adolescence. Retrieved May 20, from https://www.researchgate.net/publication/255975761_ Institutional_and_Personal_SpiritualityReligiosity_and_Psychosocial_Adjustment_in_Adolescence_Concurre nt_and_Longitudinal_Associations. https://doi.org/10.1007/s10964-013-9989-2

10. Musick, M. A., House, J. S., Williams, D. R. (2004). Attendance at Religious Services and Mortality in a National Sample. Journal of Health and Social Behavior, Vol. 45, No. 2, 198-213. https://doi.org/10.1177/ 002214650404500206

11. Pippa, N., Inglehart, R. (2004). Sacred and Secular: Religion and Politics Worldwide. Cambridge, UK: Cambridge University Press. https://doi.org/10.1007/978-3-658-13213-2_98

12. Pollack, D. (2008). Religious Change in Europe: Theoretical Considerations and Empirical Findings. Social Compass, 55(2), 168-186. https://doi.org/10.1177/0037768607089737

13. Riesebrodt, M. (2014). Religion in the Modern World: Between Secularization and Resurgence. Retrieved Mart 02, 2018 from http://cadmus.eui.eu/handle/1814/29698

14. Schieman, S. (2008). The Religious Role and the Sense of Personal Control. Sociology of Religion, Vol. 69, 273-296. https://doi.org/10.1093/socrel/69.3.273

15. Stol, J. (2008). Secularization Theory and Rational Choice. Retrieved May 20, 2018 from https://www.academia.edu/3625376/Secularization_theory_and_rational_choice._An_integration_of_micro_and_macrotheories_of_secularization_using_the_example_of_Switzerland._2008._in_D._Pollack_and_D.V. A._Olson_The_Role_of_Religion_in_Modern_Societies._New_York_Routledge_249-270

16. Tsaousis, I., Karademas, E., Kalatzi, D. (2012). The role of core self-evaluations in the relationship between religious involvement and subjective well-being a moderated mediation model. Mental Health, Religion \& Culture. Retrieved May 20, 2018 from https://www.tandfonline.com/doi/abs/10.1080/13674676.2011.651716. https://doi.org/10.1080/13674676.2011.651716

17. European social survey. Retrieved March 3, 2019 from http://www.europeansocialsurvey

\section{References}

1. Casanova, J. (2017). On the other side of secularization: The religious and secular dynamics of our global time. Kyiv: Spirit and letter.

2. Kormina, J., Panchenko, A., Shtyrkov, S. (2017). Anthropological approaches to the study of religion: theories, methods and field experiences. Forum for Anthropology and Culture, No 35, 129-166. 
3. Myronovych, D., Reshetniak, O., Salnikova, S. (2013). Religious capital and religious participation in countries of new eastern Europe. Bulletin of Taras Shevchenko National University of Kyiv : Sociology, Vol. 1, 16-27.

4. Taylor, Ch. (2014). Secularity and religion. Retrieved May 20, from http://standrews.ru/assets/files/ Books/Stranici/Tejlor-iz-Pages-18-3.pdf

5. Fedorenko, M. (2013). Religiosity, identification and religious identity. Scientific journal «Scientific notes of Orel state university", No 4, 239-241.

6. Billiet, J., Welkenhuysen-Gybels, J. (2004). Assessing Cross-National Construct Equivalence in the ESS: The Case of Religious Involvement. Paper presented at the European Conference on Quality and Methodology in Official Statistics, Mainz (Germany), 24-26 May.

7. Coleman, J. S. (1988). Social Capital in the Creation of Human Capital. American Journal of Sociology, Vol. 94, 95-120.

8. Giorgi, L. (1992). Religious Involvement in a Secularized Society. The British Journal of Sociology, Vol. 43, No 4, 639-656.

9. Good, M., Willoughby, T. (2013). Institutional and Personal/Spirituality Religiosity and Psychosocial Adjustment in Adolescence. Retrieved May 20, from https://www.researchgate.net/publication/255975761_ Institutional_and_Personal_SpiritualityReligiosity_and_Psychosocial_Adjustment_in_Adolescence_Concurre nt_and_Longitudinal_Associations. https://doi.org/10.1007/s10964-013-9989-2

10. Musick, M. A., House, J. S., Williams, D. R. (2004). Attendance at Religious Services and Mortality in a National Sample. Journal of Health and Social Behavior, Vol. 45, No 2, 198-213. https://doi.org/10.1177/ 002214650404500206

11. Pippa, N., Inglehart, R. (2004). Sacred and Secular: Religion and Politics Worldwide. Cambridge, UK: Cambridge University Press. https://doi.org/10.1007/978-3-658-13213-2_98

12. Pollack, D. (2008). Religious Change in Europe: Theoretical Considerations and Empirical Findings. Social Compass, 55(2), 168-186. https://doi.org/10.1177/0037768607089737

13. Riesebrodt, M. (2014). Religion in the Modern World : Between Secularization and Resurgence. Retrieved Mart 02, 2018 from http://cadmus.eui.eu/handle/1814/29698

14. Schieman, S. (2008). The Religious Role and the Sense of Personal Control. Sociology of Religion, Vol. 69, 273-296. https://doi.org/10.1093/socrel/69.3.273

15. Stol, J. (2008). Secularization Theory and Rational Choice. Retrieved May 20, 2018 from https://www.academia. edu/3625376/Secularization_theory_and_rational_choice._An_integration_of_micro_and_macrotheories_of_secularization_using_the_example_of_Switzerland._2008._in_D._Pollack_and_D.V. A._Olson_The_Role_of_Religion_in_Modern_Societies._New_York_Routledge_249-270

16. Tsaousis, I., Karademas, E., Kalatzi, D. (2012). The role of core self-evaluations in the relationship between religious involvement and subjective well-being a moderated mediation model. Mental Health, Religion \& Culture. Retrieved May 20, 2018 from https://www.tandfonline.com/doi/abs/10.1080/13674676.2011.651716. https://doi.org/10.1080/13674676.2011.651716

17. European social survey. Retrieved March 3, 2019 from http://www.europeansocialsurvey 